\title{
Corporate Governance, Managerial Diversion, and Indonesian State-Owned Enterprises: A Literature Review
}

\author{
Junino Jahja ${ }^{1}$, Nor Farizal Mohammed ${ }^{2}$, Norziana Lokman ${ }^{3} \&$ Norazida Mohamed ${ }^{2}$ \\ ${ }^{1}$ Faculty of Economics and Business, Universitas Indonesia, Indonedia \\ 2 Accounting Research Institute and Faculty of Accountancy, Universiti Teknologi MARA (UiTM), Shah Alam, \\ Malaysia \\ 3 Accounting Research Institute and Faculty of Administrative Science and Policy Studies, Universiti Teknologi \\ MARA (UiTM), Shah Alam, Malaysia \\ Correspondence: Junino Jahja, Faculty of Economics and Business, Universitas Indonesia, Indonedia.
}

Received: May 13, 2020

doi:10.5430/ijfr.v11n5p510
Accepted: July 15, 2020

Online Published: October 5, 2020

URL: https://doi.org/10.5430/ijfr.v11n5p510

\begin{abstract}
This paper looks at managerial diversion and agency theory and how both arguments may be applied to describe the governance practices and performance of state-owned enterprise companies in Indonesia. Managers are the main focus of the approaches, on the assumption that managers tend to expropriate the firms' and shareholders' value for their own benefit instead of looking for ways to maximize shareholders' value and fulfill their stakeholders' needs. Indonesia is selected because it has the highest number of State-Owned Enterprise (SOE) companies among the ASEAN countries. The government holds more than 51 percent of the shares and has a unique governance structure with two-tier boards to manage and run the companies. Besides, most of Indonesia's SOE companies have a tight connection with Indonesia's political party. With these characteristics, the agency problem in Indonesia's SOE companies is more prevalent compared to other listed SOE companies. The managerial diversion, which is linked to corruption, might be the principal critical factor that hinders SOE companies from performing well. Thus, even with the introduction of a good corporate governance score by the Indonesian government, which is imposed on SOE companies, it may not be able to improve the overall financial performance of SOEs as well as governance practice in the companies. This paper's objective is to review and examine prior literature on corporate governance and managerial diversion from the perspective of state-owned enterprise companies in Indonesia.
\end{abstract}

Keywords: corporate governance, state-owned enterprise, managerial diversion, agency theory, good corporate governance

\section{Introduction}

A corporate governance framework can be nicely put in place in one country. However, the execution of it is questionable, and the effectiveness of the system is yet to be explored in a market like Indonesia. This paper posits that one crucial challenge to the occurrence is due to the practice of managerial diversion. Managerial diversion arises from managers' opportunities to turn the advantage to themselves instead of shareholders (Bebchuk \& Jolls, 1999). These private benefits include using power for personal interest (Barnes, 2014; Nicols, 1967), using companies' resources for luxuries, insider trading, entertainment, self-dealing, trading stocks based on insider dealing, and many other approaches (Bebchuk \& Jolls, 1999). There are two types of managerial diversion: rent-seeking (Shleifer \& Vishny, 1997) and incentive (Fama, 1980; He, 2011). The perspective of managerial diversion is consistent with agency theory terms. An agent tends to divert the organizations' resources into personal rewards or other forms of benefit (Nicols, 1967). The government introduced corporate governance mechanisms to curb agents' self-utility. Indonesia, as an emerging market, is not left out of this development. Thus, this paper's objective is to review the literature on corporate governance and managerial diversion in the state-owned enterprise companies of Indonesia.

Indonesia has 118 state-owned enterprises (SOEs). Since 2002, the Indonesian government, as the shareholder, obliged SOEs to implement good corporate governance (GCG). SOEs were established to support government activities, such as producing public goods and services and contributing to government revenue. Owners and board 
members manage these companies like their private colleagues, which means that they also face agency problems. In this case, the agency problem occurs between the shareholder, which is the government requiring excellent performance, and the executives demanding good rewards. This requirement can lead to inappropriate consequences, such as misappropriation of assets and corruption. In 2019, there were corruption cases handled by the enforcement agencies. In Indonesia, by law, three agencies handle the corruption cases: the Indonesian Corruption Eradication Commission, the Attorney General, and the Police.

By reviewing the literature on the above matter, it offers another astounding view in presenting Indonesian SOEs' performance from the perspective of agency theory with a comprehensive discussion about managerial diversion in terms of financial and non-financial performance. Besides, the debate about corruption with underlying theory provides insights into the existing literature and sources. This paper consists of seven sections. The next section presents Indonesia's institutional background, followed by a description of Indonesia's state-owned enterprise and corporate governance. Then a discussion on managerial diversion and agency theory is given in sections 4 and 5. The final section includes the discussion, future research, and conclusion.

\section{The Institutional Background of Indonesia}

The Republic of Indonesia covers a total land area of approximately 1.9 million square kilometers and territorial waters nearly four times that size. The nation comprises over 17,000 islands that spread over 5,120 kilometers and extend across the equator from southern Thailand on the Malay Peninsula to the northeast coast of Australia. Indonesia operates as a mixed, free-market economy, including state enterprises as well as private sector businesses. State-owned enterprises (SOE) continue to play an essential role in specific economic sectors, notably petroleum products, mining, cement, and fertilizers. Besides, Indonesia's private sector is increasingly serving as the principal generator of economic growth for the country (Indonesia, 2017).

Indonesia is the world's 15th largest economy and a member of the G20. The G20 membership is a combination of the world's largest advanced and emerging economies. It represents about two-thirds of the world's population, 85 percent of global gross domestic product, and over 75 percent of global trade. G20 comprises 19 countries Argentina, Australia, Brazil, Canada, China, France, Germany, India, Indonesia, Italy, Japan, Mexico, Russia, Saudi Arabia, South Africa, South Korea, Turkey, the United Kingdom, the United States of America (USA), and the European Union. Most of the group members are Indonesia's important trading and economic companions (Board, 2019). This information indicates that Indonesia is a country that is worth examining. Table 2.1 presents Indonesia's economic statistics and the contribution of SOEs in revenue from 2012 until 2016. The statistics from the Biro Pusat Statistics-Indonesia show that SOEs contributed around 2.5 percent of the government revenue in 2015, dropped a bit to 1.9 percent in 2016, and increased to 2.3 percent in 2017. In addition, SOEs also play a critical role in providing essential goods and services that are not offered by private companies, creating jobs, supporting small businesses, and generating additional income to the government. Thus, it is critical to examine from the viewpoint of state-owned enterprises.

Table 1. Indonesian economy statistics

\begin{tabular}{llrrrrr}
\hline \multicolumn{1}{c}{ Description } & \multicolumn{1}{c}{ Unit } & 2012 & \multicolumn{1}{c}{2013} & 2014 & 2015 & \multicolumn{1}{c}{2016} \\
\hline Gross Domestic (GDP) at Current Price & Trillion rupiah & $8,615.7$ & $9,546.1$ & $10,569.7$ & $11,531.7$ & $12,406.8$ \\
\hline & Billion US\$ & 891 & 783.1 & 849.7 & 835.9 & 923.4 \\
\hline Economic Growth & $\%$ & 6.0 & 5.6 & 5.0 & 4.9 & 5.0 \\
\hline Per Capita of GDP at Current Price & Million rupiah & 35.1 & 38.4 & 41.9 & 45.1 & 48.0 \\
\hline & US\$ & 3,630 & 3.150 & 3.368 & 3.269 & 3.572 \\
\hline Inflation (y-o-y) & $\%$ & 4.3 & 8.4 & 8.4 & 3.4 & 3.0 \\
\hline Export & Billion US\$ & 190.0 & 182.6 & 176.0 & 150.4 & 145.2 \\
\hline Import & Billion US\$ & 191.7 & 186.6 & 178.2 & 142.7 & 135.7 \\
\hline Middle Rates of US\$ & Rupiah & 9,670 & 12,189 & 12,440 & 13,795 & 13,436 \\
\hline
\end{tabular}


Table 2. State-owned enterprise contribution

\begin{tabular}{llrrr}
\hline Government Revenue & Unit & \multicolumn{1}{c}{2015} & 2016 & \multicolumn{1}{c}{2017} \\
\hline Domestic Revenue & Billion Rupiah & $1,790,333$ & $1,820,514$ & $1,748,910$ \\
\hline & Million US\$ & 129,781 & 135,495 & 129,089 \\
\hline Profit transfer from SOE & Billion Rupiah & 44,000 & 34,164 & 41,000 \\
\hline & Million US\$ & 4,550 & 2,542 & 3,026 \\
\hline Contribution & $\%$ & 2.5 & 1.9 & 2.3 \\
\hline
\end{tabular}

Source: BPS-Statistics Indonesia 2018

\section{State-Owned Enterprises and Corporate Governance}

Under the prevailing law, SOEs are companies with 51 percent ownership by the Indonesian government. As government agencies, these companies enjoy facilities and support from the government. Among these facilities and support are financial, business, and subsidies. The Ministry of SOEs is the party that manages Indonesian SOEs. Its function is like a holding company, but it is headed by a cabinet member (minister). This ministry has the authority to make regulations on SOE operations. This includes, but is not limited to, recommending board members, deciding board remuneration, making the articles of association, and any other regulations or orders for SOE management. Since the government appoints board members, it can be considered to be a politically connected person (Shleifer, 1998). Besides facilities and support, SOEs also act as government agents in intervening in the economy. This role means that they are not acting simply as an ordinary corporation, as they also have a political connection. By law, Indonesia follows the two-tier system (Undang-Undang Republik Indonesia Nomor 40 Tahun 2007 Tentang Perseroan Terbatas, 2007, or, in English, Law number 40, the year 2007, about Limited Companies). In this system, board members are divided into two groups: the board of commissioners (BOCs) and the board of directors (BODs). The BODs act as executives who run the company's day to day operations, including planning and budgeting, while the BOCs act as representatives of the shareholders. Its primary duties are overseeing and advising the BOD. The government appoints both BOC and BOD members. According to the prevailing law, the BOCs act as the representative of the shareholders. They oversee and advise the BODs.

During the last cabinet of President Soeharto, in 1998, he set up a new ministry, i.e., the Ministry of State-Owned Enterprises (MSOE). Indonesia's State-Owned Enterprise Law Number 19, the Year 2003 defined SOEs as companies in which the Indonesian government owned at least $51 \%$ of the shares. The MSOE acts as the representative of the Government of the Republic of Indonesia. In 1999, the MSOE published a book entitled "Corporate Governance dan Etika Korporasi" or In English, Corporate Governance, and Corporate Ethics. This book has been used as a guide for the SOEs to implement and practice Good Corporate Governance (GCG) and corporate ethics. Since then, GCG has become a part of the performance and corporate governance indicator for SOEs. The Ministry of SOE decree Number Kep-117/M-MBU/2002 made it mandatory for all SOEs to adopt the Good Corporate Governance Practice in their daily business operations.

In 2011, the MSOE developed the GCG score to measure SOE performance in terms of its corporate governance best practices. It is hoped that by implementing this GCG framework, the government of Indonesia can increase its revenue and enhance public services through SOE companies. The MSOE, through decree number PER-01/MBU/2011, requires each SOE to appoint an independent assessor who will conduct an assessment of the implementation of GCG every two years. Instead of selecting a private assessor, the Board of Directors of the SOEs can also appoint a government institution that is competent in GCG to conduct the assessment of the SOEs. The direct appointment is recommended to avoid the procurement process, which is very rigid and time-consuming. The government institution appointed to lead GCG is Badan Pengawas Keuangan dan Pembangunan (Finance and Development Supervisory Agency) (Ministry of State-Owned Enterprises, 2011). It is the role of the board of the SOE to appoint the independent assessor.

Based on the 2015 MSOE's performance report, there are 118 SOEs in Indonesia with total assets amounting to almost IDR 5,000 trillion or USD 350 billion (Laporan Kinerja Kementerian BUMN Tahun 2015). Twenty of these SOEs are listed on the Indonesian Stock Exchange (IDX), and one of the SOEs (PT Telkom) is also listed on the New York Stock Exchange (NYSE). Due to the importance of SOEs to the Indonesian economy, the examination on 
corporate governance issues is crucial as the excellent practice may lead to better performance of companies, thus generating returns to its owner, i.e., the government.

Currently, the SOEs hold almost IDR 7,210 trillion (USD 504 billion) of assets, and they contributed a profit of IDR186 trillion (USD 13 billion) in 2017 (Bank Indonesia 2019, March 10, Informasi Kurs, retrieved from https://www.bi.go.id/id/moneter/informasi-kurs/transaksi-bi/Default.aspx). It is interesting to investigate the implementation of good corporate governance in the SOEs in Indonesia. The study's findings will add value to the growing literature on corporate governance, specifically concerning Indonesia and SOEs. Furthermore, the study also intends to provide suggestions for the government to enhance the performance and governance quality of SOEs.

Despite abundant studies on corporate governance (CG), the examination of SOEs in Indonesia can provide rich context as SOEs in Indonesia are involved in many corruption cases (Yuntho, 2019). Table 2.1 displays the SOEs in Indonesia that were accused of corruption cases in 2019. Based on data from the Corruption Eradication Commission of the Republic of Indonesia (CEC) in table 2.2, corruption cases in SOEs, from 2004 until 2016 were 38 or ranked number three from six types of government institution. For the year 2019 until November 2019, nine corruption cases were handled by the CEC (from Indonesian mass media sources). These cases mean about one example each month (refer table 2).

Academically, these corruption cases can be related to the managerial diversion concept (Barnes, 2014; Bebchuk \& Jolls, 1999; Chen, Li, Luo, \& Zhang, 2017; Nicols, 1967). Furthermore, the Indonesian government has implemented the GCG score as a tool to measure its state-owned companies' compliance with CG. Nevertheless, the positive effect of the government efforts in implementing the GCG score in SOEs is yet to be examined. Given the importance of SOEs in Indonesia, this study intends to examine whether GCG has led to better performance among SOE companies. This study also explores how agency and managerial diversion can help in explaining the reason as to why SOE companies' performance is lower compared to SOE companies listed on the Indonesian Stock Exchange. Corruption is considered part of managerial diversion (Bebchuk \& Jolls, 1999; Shaheer, Yi, Li, \& Chen, 2019). Table 2 lists the corruption cases involving Indonesian SOEs in 2019, other cases are explained in table 3 in terms of the number of cases.

Table 3. SOE corruption cases in 2019

\begin{tabular}{lll}
\hline No. & Company & Description \\
\hline 1. & Perusahaan Listrik Negara & Non-listed \\
\hline 2. & Garuda & Publicly listed \\
\hline 3. & Pupuk Indonesia & Non-listed \\
\hline 4. & Angkasa Pura II & Non-listed \\
\hline 5. & Inti & Non-listed \\
\hline 6. & Krakatau Steel & Publicly listed \\
\hline 7. & PAL & Non-listed \\
\hline 8. & Asuransi Jasa Indonesia & Non-listed \\
\hline 9. & PTPN III & Non-listed \\
\hline \multicolumn{2}{l}{ Source: mainstream Indonesian media 2019 } \\
\hline
\end{tabular}


Table 4. Corruption cases by the institution

\begin{tabular}{|c|c|c|c|c|c|c|c|c|c|c|c|c|c|c|c|c|}
\hline Institution & 2004 & 2005 & 2006 & 2007 & 2008 & 2009 & 2010 & 2011 & 2012 & 2013 & 2014 & 2015 & 2016 & Total & $\begin{array}{l}\text { Number of } \\
\text { Institutions }\end{array}$ & $\%$ \\
\hline Commission & 0 & 9 & 4 & 2 & 2 & 0 & 2 & 1 & 0 & 0 & 0 & 0 & 0 & 20 & 97 & 20.6 \\
\hline $\begin{array}{l}\text { State-owned } \\
\text { and local } \\
\text { province-owne } \\
\text { d companies }\end{array}$ & 0 & 4 & 0 & 0 & 2 & 5 & 7 & 3 & 1 & 0 & 0 & 5 & 11 & 38 & 118 & 32.2 \\
\hline $\begin{array}{l}\text { The central and } \\
\text { local } \\
\text { parliament }\end{array}$ & 0 & 0 & 0 & 0 & 7 & 10 & 7 & 2 & 6 & 2 & 2 & 3 & 15 & 54 & 20392 & 0.3 \\
\hline $\begin{array}{l}\text { Provincial } \\
\text { government }\end{array}$ & 1 & 1 & 9 & 2 & 5 & 4 & 0 & 3 & 13 & 4 & 11 & 18 & 13 & 84 & 34 & 247.1 \\
\hline $\begin{array}{l}\text { Regent and } \\
\text { cities }\end{array}$ & 0 & 0 & 4 & 8 & 18 & 5 & 8 & 7 & 10 & 18 & 19 & 10 & 21 & 128 & 514 & 24.9 \\
\hline $\begin{array}{l}\text { Ministry and } \\
\text { non-ministerial }\end{array}$ & 1 & 5 & 10 & 12 & 13 & 13 & 16 & 23 & 18 & 46 & 26 & 21 & 39 & 243 & 61 & 398.4 \\
\hline Total & 2 & 19 & 27 & 24 & 47 & 37 & 40 & 39 & 48 & 70 & 58 & 57 & 99 & 567 & & \\
\hline
\end{tabular}

Source: https://acch.kpk.go.id/id/statistik/tindak-pidana-korupsi/tpk-berdasarkan-instan

\section{Managerial Diversion}

A managerial diversion comes from transferring value from shareholders to managers (Bebchuk \& Jolls, 1999). This diversion appears in many benefits, such as using companies' resources for luxuries, insider trading, entertainment, and others (Barnes, 2014; Bebchuk \& Jolls, 1999; Nicols, 1967). The earlier literature tends to identify managerial diversion as being just another type of compensation to the managers, as a means of substituting salaries and bonuses. Therefore, value diversion benefits will offset the reduced direct compensation, thus meaning that the total managerial pay and the total wealth enjoyed by shareholders remains unchanged. Bebchuck \& Jolls (1999) began the argument that managerial diversion is harmful behavior, undesirable, and that the benefits of it are unclear.

$\mathrm{Li}$ and $\mathrm{Li}$ (2018) reported that there are two types of managerial diversion. The first type is rent-seeking, where the managers' benefits are pursued at the expense of shareholders, such as self-dealing, insider trading, embezzlement, and perquisites ( $\mathrm{Li} \& \mathrm{Li}, 2018$; Shleifer \& Vishny, 1997). According to $\mathrm{Li}$ and $\mathrm{Li}$ (2018), the second type of managerial diversion can be an incentive compensation for managers to put more effort into creating value for shareholders. The effect on value can happen if managerial diversion costs are less than other forms of incentive compensation (Fama, 1980; He, 2011). Furthermore, Li and Li (2018) discovered that managerial diversion only improves performance to a certain extent and that it is deficient if managerial diversion is excessive. They attribute the cause for bad performance due to managerial diversion if the corporate governance is weak, thereby leading to the low probability of detection and the insufficient punishment to prevent managerial diversion.

The findings of $\mathrm{Li}$ and $\mathrm{Li}$ (2018) are consistent with $\mathrm{He}$ (2011) who argued that managerial diversion occurs when monitoring is costly, and there are loose regulations, small penalties, and the consequences suffered are minor. The regulatory environment is indeed likely to influence the practice of managerial diversion. Therefore, firms' internal control system effectiveness, the effectiveness of the corporate governance of the legal regulations, and their enforcement are expected to monitor the management behavior in safeguarding the shareholders' investment (He, 2011). Another critical factor is the managerial discretion given to the managers, which is associated with industry conditions, organizational structures, and managerial traits (Finkelstein \& Hambrick, 1996). Finally, managers' specific characteristics, such as their risk-aversion, ethics, and expectation on the labor market also influence their power to extract rent from shareholders. In this case, the personal level of integrity also plays an important role. Even though one country has a very sophisticated corporate governance framework in place, the execution of the system may not be valid. He \& Ho (2011) suggested that the best corporate governance can be improved with managerial types, monitoring efficiency, and ethics education. 
The above arguments can be applied to Indonesia's situation, where the SOEs are not performing well despite the existence of a corporate governance framework. This study posits that this could be due to managerial diversion. Managerial diversion is arguable to happen in Indonesia by referring to Hand, Loyd, and Rogow (1982) that the management of firms tends to divert the firm's financial and resources from productive and effective decision-making imperfect capital markets. This diversion could be due to an ineffective monitoring system and a low level of integrity and ethical behavior. In Indonesian SOE corruption cases, BODs bribe political members to maintain their position (Yuntho, 2019). The corruption cases that involve SOEs are examples of managerial diversion (Perkins, 2004, page 20). Recent corruption cases involving SOE executives and parliament members (Yuntho, 2019) indicate that managerial diversion occurred in SOEs. Those board members who participate in such corruption cases use their companies' resources for their own related parties' interests. A recent SOE corruption case also involved parliament members who received a bribe from the SOE. These cases, so far, involve listed and non-listed SOEs (Yuntho, 2019). The listed companies are PT Garuda Indonesia and PT Krakatau Steel. Li and Li (2018) argued that SOEs are worth investigating because they operate under a soft budget constraint, where the government often helps poorly performing SOEs. Prior literature posits that SOE managers often pursue their self-interests through managerial diversion, particularly in the absence of strict control (Meng \& Perkins, 1998). Consequently, from the above review, examining Indonesian SOEs will add value, as it can give new insights into an emerging economy with such a political environment. The theory that underlies the situation is agency theory.

\section{Agency Theory}

Agency theory is about the relationship between the principal (owner) and agents, widely known as agency problems (Jensen \& Meckling, 1976). The International Finance Corporation in its publication, the Irresistible Case for Corporate Governance (2005), stated that good corporate governance would have a significant impact on a company's performance, credibility, and, in the end, give a substantial premium to its shareholders. According to agency theory (Jensen \& Meckling, 1976), corporate governance is a mechanism to control self-interest that is expected to lead to better performance. Since this study is about SOEs, where the relationship between the principal (the government) and agent (the management of the company) is involved, agency theory is the most relevant. Agency theory separates companies into two parts, the principal and the agent. The principal is the owner or shareholder, and the agent is the executive who runs the company. The different interests between the principal and the agent creates a cost to the company. The principal's interest is how to maximize their wealth by increasing the company's value, while the agents tend to choose how to maximize their reward and keep their position.

In the case of Indonesian SOEs, the MSOE, as the shareholder, requires SOEs to follow a specific corporate governance system (Ministry of State-Owned Enterprise, 2011), Ministerial decree number 1-year 2011. The aims of good corporate governance scoring (GCG) in SOEs, as stated in the SOE Ministry Decree number PER-01/MBU/ 2011, point C. 2 page 27 are 1. enhance performance control effectively; 2. optimize the effort of capitalizing SOEs' potential, and, 3. accelerate SOEs' performance growth. The above objectives of the GCG scoring are in line with agency theory, where shareholders need to control the boards (Clarke, 2007). The recent corruption cases that involved SOE executives and parliament members (Yuntho, 2019) were indications that managerial diversion happens in SOEs. Those board members who participate in such corruption cases use their companies' resources for their own related parties' interests. The recent SOE corruption case also involved parliament members who received a bribe from the SOE. These cases, so far, involve listed and non-listed SOEs (Yuntho, 2019). The listed companies are PT Garuda Indonesia and PT Krakatau Steel.

\section{Discussion and Future Research}

Despite the periodic assessment of GCG by an independent assessor, it is widely known in Indonesia that non-listed SOEs are less favorable than their private competitors. Also, many of the SOE boards of directors (BOD) members were convicted of corruption (Kompas newspaper, April 3, 2017). Fuad Rakhman (2018) compared the performance between partially privatized state-owned companies and private firms. The result was that gaps exist between those two groups of companies in which privatized SOE companies have lower financial performance than non-SOE private companies. Another study about the Indonesian banking sector's corporate governance (Ararat, Black, \& Yurtoglu, 2017) examined the relationship between corporate governance and performance. This study suggested that corporate governance implementation has a sturdy connection with bank performance.

Due to the difference in the institutional background of Indonesia from the Western market, questions may then arise as to whether the implementation of CG in Indonesian SOE's affected their performance. Maher and Thomas Andersson, from the OECD, in their paper Corporate Governance: Effects on Firm Performance and Economic Growth (1999), revealed many empirical pieces of evidence concerning the relation between GCG and firm 
performance. The measurement used the list of GCG requirements, such as board independence, transparency, and stock price (value). There have also been studies about state-owned enterprises in China that relate to SOE and political connections (Ararat et al., 2017; Gliniecki \& Law, 2017; Hung, Wong, \& Zhang, 2010). In Malaysia, there have also been studies that relate to SOEs and firm performance and political connections (Poon, Yap, \& Lee, 2013; Wong \& Hooy, 2018). So far, these kinds of studies could not be found in Indonesia. There is a study that studies Indonesian business and political connections but not for SOEs (Apriliyanti \& Kristiansen, 2018). They found that the check and balance mechanism is not working in SOEs. Perhaps, this is more prevalent in SOEs; therefore, investigating SOEs in the Indonesian market is crucial since they significantly contribute to the Indonesian economy (see Table 1).

There are Indonesian SOEs in this study (2011-2017) in a loss position, that, accounting wise, grind shareholder's equity, which is in Indonesian assets. Besides, there are corruption cases that involve SOE executives. The corruption cases involve listed SOEs and non-listed SOEs (Perkins, 2004; Yuntho, 2019). From the above, future research can examine the issues of corporate governance, state-owned companies, and performance by emphasizing the point of managerial diversion. Although it is essential and usual in developing countries, the matter of managerial diversion has not been investigated much. The study in Indonesia is critical because it can reflect similar practices in other developing countries. Hence, by examining these issues, it will contribute to the new knowledge and practice.

\section{Conclusion}

This paper has two main objectives: (i) to review prior literature on the topic of corporate governance of state-owned enterprises in Indonesia; and (ii) to outline the characteristics of managerial diversion. It links to agency theory in terms of understanding how managerial diversion affects the agency relationship between the principal (government) and agent (management of the company) in the state-owned companies and how it may present benefits to the investors, government, and other stakeholders. Implementing GCG may improve the governance structure of the state-owned companies; however, it has to be monitored and enforced against them effectively. Once this happens, the managerial diversion issue, which causes agency problems, can be reduced and slowly help the companies be vigilant against corruption and inappropriate behaviors that can cause the companies and shareholders to deteriorate further.

The implications of the study are twofold. First, to researchers, this study may enrich new ideas about Indonesian SOE characteristics, in general, and corporate governance practice, in particular. This study adds value to the knowledge concerning the effectiveness of Western corporate governance systems in the developing countries where the culture and environment differ. Second, to practitioners, the introduction of managerial diversion in Indonesian SOEs in this study raises the possibility of the corporate governance system in Indonesia serving as a rubber stamp instead of fulfilling its role in terms of a check and balance. Stakeholders and practitioners, such as shareholders, investors, and capital market authorities, may be able to put more attention on the possibility of managerial diversion.

Hence, the findings from the study prompt further investigation on the empirical evidence of the corporate governance system in Indonesia and the performance of SOEs in Indonesia. Furthermore, qualitative research can be conducted to examine the reasons for such a relationship. One limitation of the study is that it only looks in the context of one country, and, hence, a comparison of the situation among a few countries, particularly in Asian countries, would be worth exploring. Indeed, this paper contributes to the current knowledge and provides an avenue for future interesting research.

\section{References}

Apriliyanti, I. D., \& Kristiansen, S. O. (2018). The logic of political business in state-owned enterprises: the case of Indonesia. International Journal of Emerging Markets. https://doi.org/10.1108/IJOEM-08-2018-0433

Ararat, M., Black, B. S., \& Yurtoglu, B. B. (2017). The effect of corporate governance on firm value and profitability: Time-series evidence from Turkey. Emerging Markets Review, 30(September 2015), 113-132. https://doi.org/10.1016/j.ememar.2016.10.001

Barnes, P. (2014). Curbing conflicts of interest in UK building societies: Rogue building societies in the late 1950s and the Building Societies Acts of 1960, 1962 and 1986. Accounting History, 19(4), 452-474. https://doi.org/10.1177/1032373214551112

Bebchuk, L. A., \& Jolls, C. (1999). Managerial Value Diversion and Shareholder Wealth. Journal of Law, Economics, \& Organization, 15(2), 487-502. 
Board, E. (2019, June). We are G20. The Jakarta Post.

Chen, C. R., Li, Y., Luo, D., \& Zhang, T. (2017). Helping hands or grabbing hands? An analysis of political connections and firm value. Journal of Banking and Finance, 80, 71-89. https://doi.org/10.1016/j.jbankfin.2017.03.015

Fama, E. F. (1980). Agency Problems and the Theory of the Firm. Journal of Political Economy, 88(2), $288-307$. https://doi.org/10.1086/260866

Finkelstein, S., \& Hambrick, D. C. (1996). Strategic Leadership: Top Executives and Their Effects on Organizations. Minneapolis/St. Paul: West PublishingWest Publishing Company, St. Paul, Minneapolis.

Gliniecki, B., \& Law, F. (2017). Report on Corporate Governance in State-owned Enterprises - the Polish Perspective.

He, L. (2011). Managerial Diversion, Regulation, and Internal Control Mechanism. SSRN Electronic Journal, 1-41. https://doi.org/10.2139/ssrn.882865

Hung, M., Wong, T. J., \& Zhang, T. (2010). Political Considerations in the Decision of Chinese SOEs to List in Hong Kong.

Indonesia, B. P. S. R. (2017). Statistik Indonesia Statistical Yearbook of Indonesia 2017.

Jensen, M. C., \& Meckling, W. H. (1976). Theory of the Firm: Managerial Behavior, Agency Costs, and Ownership Structure. Journal of Financial Economics, 3(4), 305-360. Retrieved from papers3://publication/uuid/EB992EC7-0AE1-42D3-86A8-E36FBF1E7DCD

Li, G., \& Li, J. (2018). Managerial diversion, product market competition, and firm performance. China Economic Review, 50(601), 240-264.

Ministry of State-Owned Enterprise. (2011). PERATURAN MENTERI NEGARA BADAN USAHA MILIK NEGARA NOMOR : PER — 01/MBU/2011. Ministry of State-Owned Enterprise.

Nicols, A. (1967). Stock Versus Mutual Savings and Loan Associations : Some Evidence of Differences in Behavior. The American Economic Review, 57(2), 337-346. Retrieved from https://www.jstor.org/stable/1821636

Perkins, J. (2004). Confession of an Economic Hit Man. Berrett-Kohler Publishers, Inc San Fransisco.

Poon, W. C., Yap, A. K. H., \& Lee, T. H. (2013). The outcome of politically connected boards on commercial bank performance in Malaysia. Modern Applied Science, 7(1), 35-50. https://doi.org/10.5539/mas.v7n1p35

Shaheer, N., Yi, J., Li, S., \& Chen, L. (2019). State-Owned Enterprises as Bribe Payers: The Role of Institutional Environment. Journal of Business Ethics, 159(1), 221-238. https://doi.org/10.1007/s10551-017-3768-Z

Shleifer, A. (1998). State versus Private Ownership. The Journal of Economic Perspectives, 12(4), 133-150. https://doi.org/10.1257/jep.12.4.133

Shleifer, A., \& Vishny, R. W. (1997). A Survey of Corporate Governance.pdf. The Journal of Finance, LII(2), 737-783.

Undang-Undang Republik Indonesia Nomor 40 Tahun 2007 Tentang Perseroan Terbatas. (2007). Jakarta: House of Representative (Dewan Perwakilan Rakyat) Republik Indonesia. https://doi.org/10.1590/s1809-98232013000400007

Wong, W. Y., \& Hooy, C. W. (2018). Do types of political connection affect firm performance differently?. Pacific-Basin Finance Journal, 51, 297-317. https://doi.org/10.1016/j.pacfin.2018.08.009

Yuntho, E. (2019, June 10). BUMN Berintegritas. Kompas, p. 7.

\section{Copyrights}

Copyright for this article is retained by the author(s), with first publication rights granted to the journal.

This is an open-access article distributed under the terms and conditions of the Creative Commons Attribution license (http://creativecommons.org/licenses/by/4.0/). 